\title{
Distribution of Cryptops parisi Brolemann, 1920 (Chilopoda, Scolopendromorpha) in Poland
}

\author{
Małgorzata LEŚNIEWSKA \\ Department of General Zoology, Institute of Environmental Biology, Adam Mickiewicz University, \\ Fredry 10,61-701 Poznań, Poland,e-mail: remiz@amu.edu.pl
}

\begin{abstract}
A species hitherto regarded as very rare in Poland, found in only three sites in Lower Silesia and the Western Sudeten Mts as well as the Lower Beskid Mts, has been confirmed in the Central Sudeten Mts, the Pieniny Mts, Tatra Mts, Gorce Mts, Bieszczady Mts, Central Beskid Foothills and the Sandomierz Valley. Cryptops parisi Brolemann is a far more frequent inhabitant of the south of the country than was previously thought.
\end{abstract}

Key words: Cryptops parisi, distribution, Poland

\section{INTRODUCTION}

Cryptops parisi is a widespread European species. It has been recorded in Spain (Eason 1964), Portugal (Machado 1952), France (Brolemann 1920, 1930, Geoffroy 1979), Belgium (Lock 2000), the Netherlands (Jeekel 1977, Berg 1999), Luxembourg (Spelda 2001), Italy (Minelli \& Iovane 1987, Zapparoli 1992 a, b), Switzerland (Verhoeff 1931), Germany (Verhoeff 1931, Spelda 1999), Great Britain and Ireland (Eason 1964, Barber \& Keay 1988, Barber 1992), Scandinavia (Eason 1964), the Czech Republic (Tajovský 2001), Slovakia (Stašiov \& Maršalek 1999, Országh 2001), Austria (Matic 1972, Koren 1986), Slovenia, Croatia (Matic 1979, Kos 1992), Bosnia and Herzegovina, Yugoslavia (Kos 1992), Albania (Verhoeff 1931), Greece (Kanellis 1959), Romania (Matic 1972), Bulgaria (Stoev 2002), and also in Canada - in Newfoundland, where it has been introduced (Palmén 1954). It has not been recorded in Hungary (Fauna Europaea, 2004).

As indicated by analysis of the literature, $C$. parisi occurs in varying frequency and inhabits a range of environments depending on geographical location. South-Western Europe is regarded as the species' homeland (Kaczmarek 1979, 1980). At its northernmost limits, it displays the features of an introduced species, as it is found mostly in gardens, greenhouses and their surroundings. Palmén (1948) reported that in Eastern Fennoscandia C. parisi is a typical representative of the synanthropic element, having very little chance of becoming established there. C. parisi occurs also in Sweden under similar conditions but also out-of-doors close to human settlements (Palmén 1948).

Detailed analysis of the preferred environments of $C$. parisi in Great Britain was conducted by Barber \& Keay (1988). The species in question occurs in the South-West of the country. Along with this, the majority of reports are coastal (less than $10 \mathrm{~km}$ from the sea). In Britain the species mostly occurs in synanthropic sites. These authors indicate that only $4,1 \%$ of their standardized records were from 'rural sites'.

In Italy $C$. parisi occurs at altitudes of 20 to $2500 \mathrm{~m}$, most frequently at $400-2000 \mathrm{~m}$. It is very common in mesophilous woodlands. It is sometimes found in man-made environments or in mole burrows and in caves (Minelli \& Iovane 1987). According to Zapparoli (1992 a) the species seems to be rarely found in the urban area of Rome. In Bulgaria C. parisi is 
extremely common. It occurs at altitudes of 100 to $1850 \mathrm{~m}$. Among habitats occupied Stoev (2002) lists coniferous and deciduous forests, subalpine habitats, urban habitats, caves. In Slovakia the species prefers warmer sites, occurring in forests, especially mountain ones, it is also reported in caves (Országh 2000). In Romania C. parisi is common, often found in deciduous forest litter, though it has also been reported in caves (Matic 1972). Unfortunately, the majority of authors do not give further details on the autecology of the species.

In Poland it has been reported from three sites: Lower Silesia, the Ślęża Massif as well as from two towns: Jelenia Góra and Szklarska Poręba in the West Sudeten Mts (Kaczmarek 1980). Finally, it has been collected in the Lower Beskid Mts (Leśniewska \& Taborska 2003). Since then a number of sites in Southern Poland have been recorded.

The present work aims to provide current data on the occurrence of the species in Poland and to summarize the recent knowledge on this subject.

\section{MATERIALS AND METHODS}

The material covers the years 1953-2002. It includes specimens of Cryptops parisi in the collection of the Department of General Zoology of Adam Mickiewicz University in Poznań (samples collected by Jadwiga Kaczmarek (JK), Maria Niewiarowska-Olszanowska (MN), Mirosława Klatt-Więckowska (MK), Róża Krysztofiak (RK), Małgorzata Taborska (MT), Małgorzata Leśniewska (ML), Piotr Leśniewski (PL). In addition, some samples were borrowed from the Museum and Institute of Zoology of the Polish Academy of Sciences in Warsaw (the material collected by Wojciech Staręga (WS), Cezary Dziadosz (CD), the Team from the Institute of Zoology of the Polish Academy of Sciences, Warsaw (MIZ). All specimens were identified by the author. Data from literature were also considered in the site listing and signed by the star (*).

The species was found by direct searching under stones, bark, dead logs, branches and other microhabitats as well as in soil-litter samples and sifted litter.

\section{RESULTS}

117 specimens of Cryptops parisi in 53 samples from 44 sites have been recorded. Below are cited all current confirmations of the species. The distribution of sites is shown at Fig. 1.

\section{Lower Silesia}

*4.06.1953. Ślęża Massif, under stones near a waterfall, 1 specimen, leg. RK, UTM: XS13 (KACZMAREK 1979, 1980);

Western Sudeten Mts

*19.04.1953. Szklarska Poręba, mixed forest, in litter, 1 specimen, leg. RK, UTM: WS33 (Kaczmarek 1979, 1980);

*Jelenia Góra, leg. JK, UTM: WS53 (Kaczmarek 1979, 1980).

Central Sudeten Mts

- 13.08.1964. Polanica-Zdrój, deciduous forest, by a path, in litter, 1 specimen, leg. MK, UTM: XR08;

- 30.06.1965. Bystrzyca Kłodzka, by a river, in litter, 1 specimen, leg. MK, UTM: XR17;

- $\quad$ 1.07.1965. Bystrzyca Kłodzka, old cemetery, 1 specimen, leg. MK, UTM: XR17;

- $\quad$ 5.07.1965. Bystrzyca Kłodzka, arboretum, beneath a large oak, I specimen, leg. MK, UTM: XR17;

- $\quad$ 16.08.1965. Polanica-Zdrój, garden, in leaf 1itter, l specimen, leg. MK, UTM: XR08;

- 28.08.1965. Sokołówka, deciduous forest, in litter, l specimen, leg MK, UTM: XR08. 
Tatra Mts

- 17.07.1975. Opalone Mt, sloping spruce forest, under stones, 1 specimen, leg. JK, UTM: DV35;

- 19.07.1975. Dolina Roztoki, spruce forest, close to a stream, under stones, 4 specimens, leg. JK, UTM: DV25;

- 23.07.1975. Dolina Roztoki, spruce forest, under stones, 3 specimens, leg. JK, UTM: DV25.

Gorce Mts

12.07.1975. Lubań Mt, - slope; spruce forest, in litter, I specimen, leg. JK, UTM: DV58.

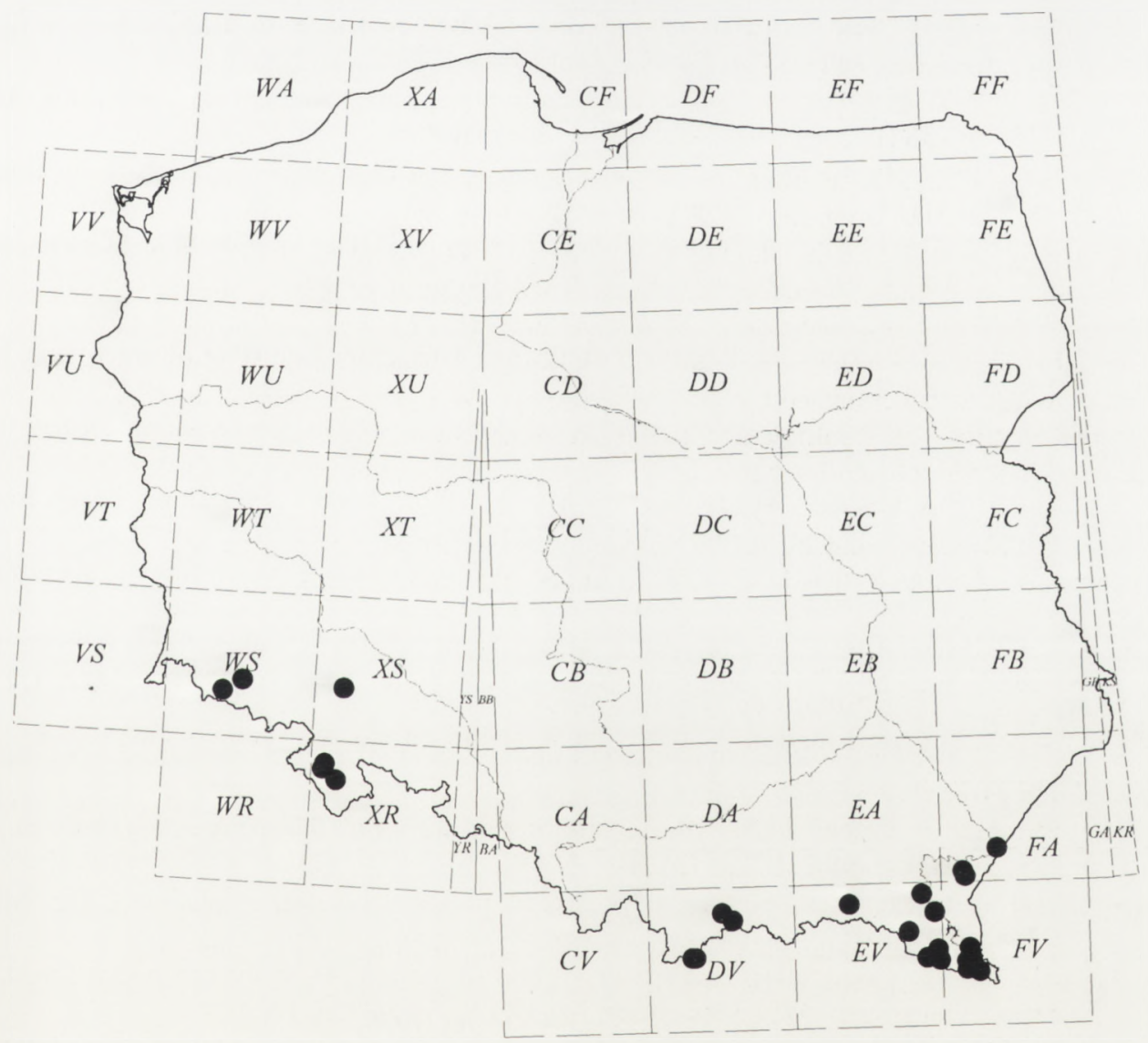

Fig 1: Known localities of Cryptops parisi in Poland

Pieniny Mts

15.07.1995. Krościenko, Pieniński stream valley, Carpathian beech forest, litter and soil, 7 specimens, leg. ML \& PL, UTM: DV57;

- 7.09.1995. Krościenko, Pieniński stream valley, Carpathian beech forest, litter and soil, 4 specimens, leg. ML \& PL, UTM: DV57;

- 13.08.1996. Krościenko, Pieniński stream valley, Carpathian beech forest, litter and soil, 5 specimens, leg. ML \& PL, UTM: DV57. 
Lower Beskid Mts

*27.06.2001. Kiczera Żydowska, Carpathian beech forest, litter, $0.5 \mathrm{~m}$ from a dead trunk, 1 specimen, leg. MT, UTM: EV38 (Leśniewska \& Taborska 2003);

*27.06.2001. Kiczera Żydowska, Carpathian beech forest, litter, $1.5 \mathrm{~m}$ from a live beech trunk, 1 specimen, leg. MT, UTM: EV38 (Leśniewska \& Taborska 2003);

*27.06.2001. Kiczera Żydowska, Carpathian beech forest, litter, $0.5 \mathrm{~m}$ from a sycamore, 2 specimens, leg. MT, UTM: EV38 (Leśniewska \& Taborska 2003);

*27.06.2001. Kiczera Żydowska, Carpathian beech forest, litter, next to a crumbling tree trunk, 3 specimens, leg. MT, UTM: EV38 (Leśniewska \& Taborska 2003);

*27.06.2001. between Krempna and Żydowskie, Carpathian beech forest, litter, next to an anthill, 1 specimen, leg. MT, UTM: EV38 (Leśniewska \& Taborska 2003);

*29.06.2001. Next to the Rozstajne forester's hut, fir forest, in litter beneath a fir, 5 specimens, leg. MT, UTM: EV38 (Leśniewska \& Taborska 2003);

*1.07.2001. Kiczera Żydowska, Carpathian beech forest, litter, 1 specimen, leg. MT, UTM: EV38 (Leśniewska \& Taborska 2003);

*2.07.2001. By the road to Ciechania, larch forest, litter next to a larch, 1 specimen, leg. MT, UTM: EV38 (Leśniewska \& Taborska 2003);

*25.09.2002. Krempna, Carpathian beech forest, soil-litter sample, 4 specimens, leg. MT, UTM: EV38 (Leśniewska \& Taborska 2003).

Bieszczady Mts

21.05.1963. Dwernik, undergrowth on the left bank of the San river, 4 specimens, leg. WS, UTM: FV15;

- 24.05.1963. Dwernik-Kamień, east facing slope, ca. $650 \mathrm{~m}$, beech and hazel forest, 1 specimen, leg. WS, UTM: FV15;

- 29.05.1963. Ustrzyki Górne, Kiczera Mt, ca. 700 m, west facing slope, beech forest above a stream, 3 specimens, leg. CD, UTM: EV67;

- 30.05.1963. Ustrzyki Górne, valley of the Wołosatka stream, beech forest, 1 specimen, leg. CD, UTM: FV23;

- 12.07.1963. Cisna, Rożki Mt, north facing slope, ca. $600 \mathrm{~m}$, mixed forest (spruce, fir, beech, sycamore), in a shady mountain stream gully, 2 specimens, leg. MIZ, UTM: EV95;

- 15.07.1963. Cisna, leafy undergrowth above the Hobkowiecki stream, 2 specimens, leg. MIZ, UTM: EV95;

- 16.07.1963. Cisna, Jasło Mt, mountain pasture near the peak, ca. 1000 m., 6 specimens, leg. MIZ, UTM: EA31;

- 19.07.1963. Balnica, evergreen forest and meadow bushes, 1 specimen, leg. MIZ, UTM: EV84;

- $\quad$ 10.08.1963. Valley between Tarnica Mt and Krzemień Mt, sycamore-beech forest, in a mountain stream gully, 1 specimen, leg. CD \& WS, UTM: FV23;

- 30.09.1963. Magura Stuposiańska Mt, west facing slope, ca. $650 \mathrm{~m}$, mixed forest (beech, fir, spruce), 1 specimen, leg. WS, UTM: FV24;

- 5.11.1963. Lubne Mt, south-east facing slope, ca. $700 \mathrm{~m}$, mixed forest (fir, yew, spruce, sycamore, beech), in a mountain stream gully, 1 specimen, leg. CD \& WS, UTM: EV97;

- 25.09.1964. Ustrzyki Górne, in a small mountain stream gully, beech forest without undergrowth, 1 specimen, leg. WS, UTM: FV23;

- 18.06.1965. Komańcza-Letnisko, Osławica stream embankment, beneath a railway bridge, under stones in grass, 1 specimen, leg. WS, UTM: EV76; 
25.08.1966. Wielka Semenowa Mt, slope, beech forest, in litter, 1 specimen, leg. JK, UTM: FV13;

26.08.1966. Połonina Caryńska Mt, slope, beech forest, in a crumbling trunk, 2 specimens, leg. JK, UTM: FVI4;

- 17.10.1966. Cisna, Rożki Mt, north facing slope, ca. $600 \mathrm{~m}$, beech-fir forest, in a mountain stream gully, in litter, 1 specimen, leg. WS, UTM: EV95;

30.08.1967. Jasło Wielkie Mt, slope, beech forest, in litter, 1 specimen, leg. JK, UTM: EV94;

6.08.1973. Dwernik, in the gully of the Caryński stream, beech-sycamore-fir forest, 1 specimen, leg. CD \& WS, UTM:FVI5.

Central Beskid Foothills

Bukowsko Foothills

- 30.08.1968. Sanok - skansen, deciduous forest (beech, hornbeam, oak, maple, alder, hazel), in litter, among rocks, by the fence of an Orthodox church, 1 specimen, leg. JK, UTM: EV89.

Przemyśl Foothills

The specimens of $C$. parisi were found in the Przemyśl Foothills during research in the years 1991-93 (Wytwer, unpublished data). Sites (UTM: FA10):

- 25.04.1991. Arłamów - beech forest, trunks, 3 specimens; litter, 7 specimens;

- 24-25.08.1991. Arłamów - beech forest, litter, 13 specimens; trunk, 1 specimen;

- 4.07.1992. Arłamów - beech forest, rotting wood, 1 specimen; litter, 1 specimen;

- 14.09.1993. Cisowa mixed forest, litter, 1 specimen;

- 8.07.1992. Posada Rybotycka - beech forest, litter, 1 specimen;

- 8.08.1992. Posada Rybotycka - beech forest, litter, 2 specimens;

- 7.05.1992. Trójca - undergrowth among ruins, litter, 1 specimen;

- 22.08.1991. Wojtkowa - pine forest, litter, 1 specimen.

Sandomierz Valley

20.07.1962. Torki near Medyka, willow trunk above a ditch, 1 specimen, leg. MN, UTM: FA32.

\section{CONCLUSIONS AND DISCUSSION}

Cryptops parisi has been confirmed in several regions in Southern Poland. It occurs in Lower Silesia, the Western Sudeten Mts, the Lower Beskid Mts, the Central Sudeten Mts, the Pieniny Mts, Tatra Mts, Gorce Mts, Bieszczady Mts, Central Beskid Foothills and the Sandomierz Valley (Fig. 1).

In Poland $C$. parisi occurs both in natural environments as well as in synanthropic ones (Fig. 2). The broad range of habitats occupied is typical. The species is found equally in deciduous, coniferous or mixed forests but the greatest number of records comes from beech forests. It is no stranger to open spaces either. It occurs in gardens, urban parks and cemeteries, in environments with varying soil structures, litter and humidity. In the light of the data gathered, it seems reasonable to assume that the species is common in the south of Poland. Due to the lack of quantitative research we cannot draw conclusions as to the frequency levels in individual environments. The comparatively larger number of records from beech forests may be associated with the greater frequency of research conducted in forest environments. In Poland the species concerned reaches a northern limit of its occurrence in natural sites, though the course of this limit is still not known and requires further research.

Though only a few authors provide more exhaustive analysis concerning the environments and micro-habitats occupied by $C$. parisi, it can be stated that in the majority of cases given, 
the species in question occurs, as in Poland, in both natural and man-made environments. This is the case in Italy (Minelli \& Iovane 1987), Bulgaria (Stoev 2002) and Romania (Matic 1972). In Northern Europe it occurs mainly in synanthropic environments (Palmén 1948, Barber \& Keay 1988).

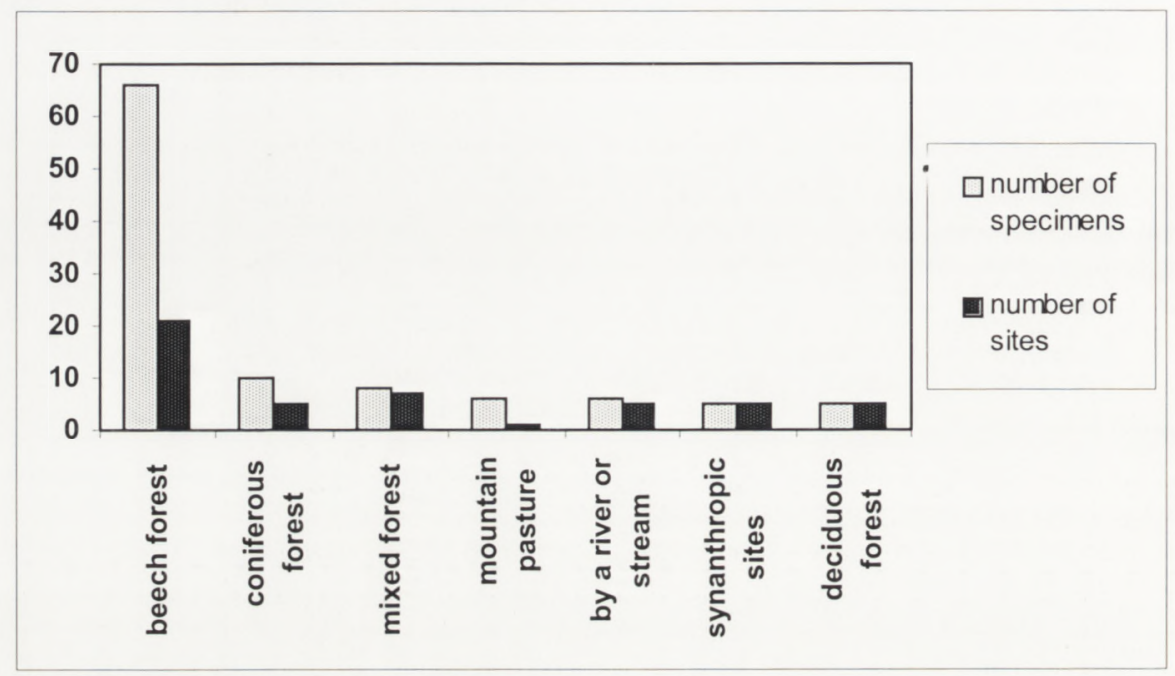

Fig 2. Preferred habitats of Cryptops parisi in Poland.

The lack of earlier data concerning the occurrence of this, as it turns out, frequently occurring species, in the south of Poland, may be related to its erroneous identification and its being confused with the common lowland species $C$. hortensis Leach, 1814. A third species of the genus Cryptops - C. anomalans Newport, 1844, can be expected in Poland, the more so, since it has been confirmed in countries adjoining Poland (Eason 1964, Voigtländer 1988).

\section{ACKNOWLEDGEMENTS}

My sincere thanks go to Dr J. Wytwer for providing access to the information concerning the occurrence of the species in the Przemyśl Foothills.

I would also like to thank anonymous reviewers for their very constructive criticism.

\section{REFERENCES}

BARBER A. D. 1992. Distribution and habitat in British centipedes (Chilopoda). Ber. Nat.-med. Verein Innsbruck, Suppl. 10: 339-352.

Barber A. D. \& KeAy A. N. 1988. Provisional Atlas of the centipedes of the British Isles. Biological Records Centre, Huntingdon: 127pp.

BERG M.P. 1999. Naamlijst van de Nederlandse duizendpoten (Myriapoda: Chilopoda). Nederlandse faunistische Mededelingen 8: 67-76.

Brolemann H. W. 1920. Un nouveau Cryptops de France (Myriapodes). Bull. Soc. Hist. Nat. Toulouse, 48, 9-11.

Brolemann H. W. 1930. Eléments d'une faune des Myriapods de France: Chilopodes. Faune de France. Vol. 25.

Paris: Librairie de la Faculté des Sciences, 405pp.

EASON E. H. 1964. Centipedes of the British Isles. London: Warne, 294pp.

FAUNA EUROPAEA 2004. http://www.faunaeur.org/distribution-table.php.

Geoffroy J.- J. 1979. Les peuplements de Chilopodes et de Diplopodes d'une chênaie - charmaie. Thèse du Diplôme de Docteur. L'Université Pierre et Marie Curie, Paris, 180 pp.

JEEKEL C. A. W. 1977. Voorlopige atlas van de verspreiding der Nederlandse duizendpoten (Chilopoda). Verslagen en

Technische Gegenvens. Unstituut voor Taxonomische Zoölogie (Zoölogisch Museum), Universiteit van Amsterdam, No. 13, 56 pp. 
KaCzmarek J. 1979. Pareczniki (Chilopoda) Polski. Wydawnictwo Naukowe Uniwersytetu im. A. Mickiewicza. Seria Zoologia, 9, 100 pp.

KaCZMAREK J. 1980. Pareczniki (Chilopoda). Katalog Fauny Polski, 14, (4), PWN, Warszawa, 44 pp.

KANELLIS A. 1959. Die Chilopodenfauna Griechenlands, Thessaloniki, 56 pp.

Koren A. 1986. Die Chilopoden-Fauna von Kärnten und Osttirol. 1. Geophilomorpha, Scolopendromorpha. Teil I. CARINTHIA II. Klagenfurt, 88 pp.

KOS I. 1992. A review of the taxonomy, geographical distribution and ecology of the centipedes of Yugoslavia (Myriapoda, Chilopoda). Ber. Nat.-med. Verein Innsbruck, Suppl. 10: 353-360.

LEŚNIEWSKA M. \& TABORSKA M. 2003. Centipede community of a beech forest in Magura National Park, Poland. Fragm. Faun., 46: 109-119.

LOCK K. 2000. Checklist of the Belgian centipedes (Myriapoda Chilopoda). Bull. S.R.B.E./K.B.V.E, 136: 87-90.

MACHADO A. 1952. Miriápodes de Portugal. Primeira parte: Quilopodes. Broteria 21, 65-169.

Matic Z. 1972. Fauna Republicii Socialiste România, Clasa: Chilopoda, Subclasa Epimorpha, 6, 2, Bucuresti, 224 pp.

Matic Z. 1979. Nouveautes sur la faune des Chilopodes de Yougoslavie. Biol. vestn, Ljubljana, 27, 2: 147-155.s

Minelli A. \& Iovane E. 1987. Habitat preferences and taxocenoses of Italian centipedes (Chilopoda). Boll. Mus. civ. St. nat. Veneria, 37: 7-34.

OrszáGH I. 2000. Centipedes (Antennata, Chilopoda) from some caves in Slovakia, pp. 129-140. In: MocK A., KovÁČ L., FUlin M. (eds), Fauna jaskýň. Východoslovenské múzeum, Košice:, 200 pp. [In Slovak]

ORSZÁGH I. 2001. Centipedes (Chilopoda) of the Slovak Republic. Myriapodologica Czecho-Slovaca, 1: 49-58.

PALMÉn E. 1948. The Chilopoda of Eastern Fennoscandia. Arch. Soc. "Vanamo". 13, (4): 1-46.

PALMÉn E. 1954. Survey of the Chilopoda of Newfoundland. Arch. Soc. "Vanamo". 8, (2):131-149.

SPELDA J. 1999. Die Hundert - und Tausendfüßerfauna zweier naturaldwaldreservate in Hessen (Myriapoda: Chilopoda, Diplopoda). Carolinea 57: 101-110.

SPELDA J. 2001. Faunistic investigations on the soil fauna at the Muellertal (Luxembourg): Chilopoda, Diplopoda, Isopoda, Opiliones. Andrias 15: 49-53.

STAŠIOV S. \& MARŠALEK P. 1999. Stonôžky (Chilopoda) CHKO-BR Polana. Ochrana prírody, Banská Bystrica, 17: $163-168$.

STOEV P. 2002. A catalogue and key to the centipedes (Chilopoda) of Bulgaria. Pensoft, Sofia-Moscow, 104 pp.

TAJOvSKÝ K. 2001. Centipedes (Chilopoda) of the Czech Republic. Myriapodologica Czecho-Slovaca, 1: 39-48.

VERHOEFF K. W. 1931. Über europäische Cryptops-Arten. Zool. Jb. (Systematik) 62, 3: 263-288.

VOIGTLÄNDER K. 1988. Für die DDR neue oder seitene Myriapoden (Diplopoda, Chilopoda). Abh. Ber, Naturkundemus. Görlitz 62, 10: 21-25.

ZaPPAROLi M. 1992a. Centipedes in Urban Environments: Records from the City of Rome(Italy). Ber. nat.-med. Verein Innsbruck. Suppl. 10: 231-236.

ZAPPAROLI M. 1992b. Preliminary data on centipede communities of Quercetea ilicis and Fagetalia sylvaticae in Central Italy. Ber. nat.-med. Verein Innsbruck. Suppl. 10: 197-203.

\section{STRESZCZENIE}

\section{[Występowanie Cryptops parisi Brolemann, 1920 (Chilopoda, Scolopendromorpha) w Polsce]}

Cryptops parisi, gatunek uważany dotychczas za bardzo rzadki w Polsce, był podawany jedynie z trzech stanowisk na Dolnym Śląsku i w Sudetach Zachodnich oraz z Beskidu Niskiego. Prezentowana praca zawiera aktualne informacje o występowaniu $C$. parisi w wielu innych regionach na południu kraju. Gatunek stwierdzono w Sudetach Środkowych, Pieninach, Tatrach, Gorcach, Bieszczadach, Pogórzu Środkowobeskidzkim oraz w Kotlinie Sandomierskiej (Fig. 1). W Polsce C. parisi zasiedla zarówno siedliska naturalne, jak i synantropijne (Fig. 2), jednak najwięcej dotychczasowych stwierdzeń pochodzi z buczyny karpackiej. 